\title{
Emerging synergies on the co-treatment of spent coffee grounds and brewer's spent grains for ethanol production
}

\section{Christos Grammatikos}

National Technical University of Athens: Ethniko Metsobio Polytechneio

\section{Vassileia Stoumpou}

National Technical University of Athens: Ethniko Metsobio Polytechneio

Elli Maria Barampouti ( $\sim$ belli@central.ntua.gr)

National Technical University of Athens https://orcid.org/0000-0003-4871-8786

\section{Sofia Mai}

National Technical University of Athens: Ethniko Metsobio Polytechneio

Dimitris Malamis

National Technical University of Athens: Ethniko Metsobio Polytechneio

\section{Maria Loizidou ( $\nabla$ mloiz@chemeng.ntua.gr)}

National Technical University of Athens: Ethniko Metsobio Polytechneio

\section{Research Article}

Keywords: agro-waste, enzymatic hydrolysis, oil extraction, valorisation

Posted Date: May 14th, 2021

DOI: https://doi.org/10.21203/rs.3.rs-425585/v1

License: (c) (i) This work is licensed under a Creative Commons Attribution 4.0 International License. Read Full License 


\section{Abstract}

Purpose: Given that the depletion of fossil fuels is an important issue that should be tackled urgently, alternative routes are being sought for biofuels production. This paper, under this context, studied the potential synergies of co-treatment of two kinds of agro-waste (brewers' spent grains, BSG and spent coffee grounds, SCG) towards the direction of biodiesel and bioethanol production, alleviating at the same time their treatment and management issues.

Methods: The technical feasibility of oil extraction and ethanol production was studied and optimized in both laboratory and bench scale. A treatment train including alkaline pretreatment of SCG and dilute acid pretreatment of BSG, neutralization of the solutions by mixing them, enzymatic saccharification and ethanolic fermentation led to the production of bioethanol.

Results: The co-treatment of BSG and SCG proved beneficial and optimum experimental conditions were defined by setting the bioethanol production cost as optimization parameter. The lowest ethanol production cost (3.9€/ kg) was observed for scenario 4 (SCG/BSG mixture, chemical pretreatment $(0.5 \mathrm{~N}, 5 \mathrm{~h})$, enzymatic hydrolysis (400 $\mu \mathrm{L} / \mathrm{g}$ cellulose, $16 \mathrm{~h}))$ and scenario 5 (SCG/BSG mixture, chemical pretreatment $(0.5 \mathrm{~N}, 5 \mathrm{~h})$, enzymatic hydrolysis ( $800 \mu \mathrm{L} / \mathrm{g}$ cellulose, $5 \mathrm{~h})$ ). Further upscaling of the process verified the technical feasibility of process units leading to a further increase of ethanol yield and thus a decrease in the production cost.

Conclusion: Conclusively, it was demonstrated that the recovery and extraction of the oil content of BSG and SCG and the achievement of high ethanol yields is technically feasible. Within this context, an integrated biorefinery was presented, making evident that these substrates could reverse the eminent energy crisis via biofuels production.

\section{Statement Of Novelty}

The novelty of this work is the co-treatment of two agro-wastes (spent coffee grounds and brewers' spent grains) towards biodiesel and bioethanol production. To our knowledge, the experimental set-up including the acidic pretreatment of BSG and the alkaline pretreatment of SCG followed by the enzymatic hydrolysis of the mixture was examined for the first time during this study. The main benefits of the co-treatment are the absence of a neutralisation stage avoiding the respective cost and the improved efficiencies of the bioprocesses. Based on the lab and bench scale experiments and a preliminary cost analysis presented, a biorefinery conceptual design is proposed where the synergistic effect of the co-treatment was made evident. Thus, this innovative process will allow to mitigate the adverse environmental impacts of fossil fuels without affecting with the entire food chain.

\section{Introduction}

In the concept ("reduce reuse recycle recover") of circular economy and energy security, waste is considered as a valuable source for further exploitation. Current industrial activity generates a substantial amount of biomass bioproducts that are left unused, despite their multi-dimensional contribution potential to the development of value-added products.

Through the entire food supply chain, from harvesting and processing to the final consumable foodstuff, edible and inedible parts of the original organic materials are discarded. The agro-food industry itself is responsible for the $19 \%$ of the overall food waste generated. Approximately $17 * 10^{6}$ tons of waste are accumulated from the processing and manufacturing of beverages and food products per year in the EU [1].

Taking into account the emerging demand for renewable energies on European level, agro-food wastes have been attracting much attention as potential biomass feedstock for bioenergy and biofuel production.

The EU statistical report 2020 determines the overall fuel demand in Europe to 405 Mtoe, implying that at least 56 Mtoe of energy should be supplied by biofuels to fulfil the EU commitment. Currently, blends of fossil fuels with liquid biofuels are used as renewable energy sources in transportation. Among the most widely produced biofuels stands biodiesel and

Page 2/18 
biogasoline, which in 2017 represented respectively 12 Mtoe and 2.5 Mtoe of produced energy in the EU [2]. Bioethanol is primarily produced by first generation feedstocks, based on sugars and starch, such as maize, wheat and sugarbeet. However, the competition with land, water and the human food supply that has arisen from their extended use, has rendered its continuing exploitation unsustainable. Alternative feedstocks based on lignocellulosic biomass (second generation feedstocks) have been attracting much attention as a viable substitute of food crops. Abundant in different forms (agricultural, wood, forest residues, industrial wastes, organic fraction of municipal solids wastes), produced in large quantities, easily accessible and available with promising compositional characteristics, when undergone specific processes can yield sufficient amounts of valuable components to be valorized into sustainable pathways [3].

The production of lignocellulosic ethanol is often reported in literature, based mainly on the valorization of single feedstocks, while mixed feedstocks have been poorly explored[4, 5]. Since the former is reliant upon the continuous availability and supply of the raw materials, its full-scale production is highly stimulated by extraneous factors. Such bottlenecks constitute the seasonal fluctuation of substrates influencing their availability, storage and transportation costs, intrinsic characteristics of the biomass demanding special handling or processing (low bulk density, recalcitrance) but also the competitive uses of the available feedstocks (soil enhancement, domestic fuel) [4].

The mixed biomass concept, by simultaneously utilizing two or more different types of biomass, of similar or different origin, in varying proportions, can provide an efficient alternative both from a practical and technical viewpoint [4]. The combination of feedstocks can outbound the insufficiencies of individual substrates, promote the synergetic supplementation of nutrients, minimize the need of external supplements addition, improve the quality of the overall feedstock (carbohydrates content, ash)[6], ensure the continuous availability of feedstock, thereby increasing the throughput of existed installations and their cost savings. While only a few laboratory-scale studies have investigated the feasibility of the mixed feedstock approach, benefits reported include: enhanced removal of lignin, lower concentration of inhibitors in the hydrolysate mixtures, increased sugar recovery in pretreated mixtures and occasionally higher ethanol yields achieved, compared to single substrate trials [7-9].

Given the high popularity of their marketable products, beer and coffee industries are two of the most active waste generators in the agro-food sector.

Beer brewing rejects different types of waste among which brewers' spent grains (BSG) have the highest accumulation factor [10]. The overall brewing process includes several biochemical reactions (malting of barley grains, mashing, boiling, fermentation to ethanol), that break down the malt starch to fermentable sugars. BSG is the solid fraction separated from the wort after mashing and it represents $30 \%$ of the original malt weight. Approximately $20 \mathrm{~kg}$ of BSG are produced per $100 \mathrm{~L}$ of beer indicating that about $8 * 10^{6}$ tons of BSG are produced per year only in the EU [11].

On the other hand, spent coffee grounds (SCG) are the primary residue generated from the brewing of coffee. They represent the $45 \%$ of the initial coffee bean, after it has been treated to release its constituents (aromas, flavors) to the consumable coffee liquid [12].

Agro-wastes from industrial food processing, have been reported to present fluctuating characteristics. BSG and SCG are high in organic content and other nutritional valuable compounds ranging from fibers and sugars to protein, vitamins, minerals and antioxidants, rendering them promising raw materials for food and non-food applications. The chemical composition of both BSG and SCG is directly linked to the initial barley grains and coffee beans respectively. They are principally lignocellulosic materials, with high fiber content in the form of cellulose (12-26\% w/w for BSG and 7-15\% w/w for SCG), hemicellulose (19-42\% w/w for BSG and 28-42\% w/w for SCG), lignin (7-28\% w/w for BSG and up to 33\% w/w for SCG), lipids (0-11\% w/w for BSG and 2-24\% w/w for SCG) and proteins (15-30\% w/w for BSG and 6-18\% w/w for SCG) [1315]. 
Their composition varies with the grain or bean variety, harvesting time, brewing conditions applied or secondary raw materials involved in the process of brewing. Table 1 presents the variations in structural components reported in literature for both grain substrates.

Until now, spent grains have been used as animal feed given their high nutritional value (fibers, protein, vitamins and aminoacids). Given their increased production, incorporation to fertilizing products, composting or landfilling practices have also been reported as alternatives in handling the large volumes accumulated[12]. However, problems related to their disposal (biological instability, odors generation, autoxidation susceptibility, spoilage and potential toxicity of several constituents) have led the updated environmental legislation, to introduce sustainable management practices aiming to prevent waste generation and minimize their environmental footprint [12]. By reclaiming the compositional interest of the recovered biomass streams, valuable compounds can be extracted thereof or directly be transformed to new marketable products and bioenergy. In recent years, extended research has been dedicated to either BSG or SCG streams as potential feedstocks for biodiesel and bioethanol production.

While the biodiesel potential of agro-food wastes is often mentioned in literature, few studies have experimentally proven their relevant suitability. SCG has been more extensively investigated with a few studies reporting successful oil extraction and biodiesel production thereof [16, 17], whereas only one recent study reveals the feasibility for BSG [18].

The bioethanol route involves an alternated sequence of processes including pretreatment of the lignocellulosic biomass, hydrolysis of polysaccharides to their monomer sugars (mainly glucose, xylose, arabinose) and fermentation. The final product is received by distillation of the fermented liquor. BSG and SCG hydrolysates have been widely investigated in literature as for their bioethanol potential with variations regarding the pretreatment conditions, the types and dosage of saccharifying enzymes for hydrolysis as well as the fermenting agents applied. Pretreatment is an essential step in the bioconversion route, that degrades the recalcitrant lignocellulosic fibers and facilitates the subsequent step of enzymatic hydrolysis. Among the pretreatment techniques most commonly reported for BSG and SCG (alkaline, acidic, steam explosion, ionic liquid $[19,20]$ alkaline pretreatment appears more effective in conditioning the lignocellulosic biomass and partially decrystallizing cellulose, thereby increasing the accessible surface area for hydrolytic enzymes [21], whereas acid pretreatment has also been reported as a fast and efficient pretreatment method in some cases [22]. Regarding fermentation of both substrates, an investigation of a variety of yeasts (Saccharomyces cerevisiae, Pichia stipites, Kluvyveromyces fragilis) [23] has outlined S. cerevisiae as the strain providing generally the highest ethanol yields.

According to our previous work SCG and BSG has the potential to be valorised for bioediesel and bioethanol production [20, $24,25]$. It has been proved that this is feasible when chemical pretreatment is applied; alkaline pretreatment for SCG and dilute acid for BCG. However, the high amount of chemicals used for both the chemical pretreatment and neutralization prior to enzymatic hydrolysis render the whole process problematic in economic and resource-efficient terms. Thus, this study aims to investigate possible synergies in the co-treatment of SCG and BSG towards a sustainable biodiesel and bioethanol production.

\section{Materials And Methods}

\section{$2.1 \quad$ Feedstocks}

Brewers' Spent Grains (BSG) were provided by the Hellenic Breweries of Atalanti (EZA), located in Atalanti, Fthiotida province, Greece. The BSG were received in the premises of UEST (Unit of Environmental Science and Technology, School of Chemical Engineering, National Technical University of Athens, Greece), and were subjected to further processing. Processing involved simultaneous milling and dehydration using GAIA GC-100, a rotary drum dryer suitable for food waste, which operated for 14 hours at $105^{\circ} \mathrm{C}$. The substrate was dried up to $3.3 \%$ moisture, was physico-chemically characterized and stored at room temperature prior to further processing. 
Spent Coffee Grounds (SCG) samples were periodically collected from the coffee-shop of the School of Chemical Engineering, in the National Technical University of Athens, Greece, over a period of 3 months. Each batch was dried for $24 \mathrm{~h}$ at $105^{\circ} \mathrm{C}$ to minimize the occurrence of microbial growth. All samples were physico-chemically characterized and stored at room temperature prior to further processing.

\section{$2.2 \quad$ Experimental set-up}

The oil extraction, chemical pretreatment, enzymatic saccharification and fermentation were the main processes that were studied in laboratory and bench scale. Lab scale experiments were carried out in autoclavable bottles (200 mL) using an Incubator Shaker (IKA-KS 3000i), while bench scale experimenting in a 4L mechanically stirred reactor with double walls.

\subsection{Oil extraction}

For laboratory scale experiments, the conventional Soxhlet extraction process was adopted and operated for 4 hours with $\mathrm{n}$ hexane as solvent at a solid to solvent ratio 1:20 (g/mL), based on previous studies optimizing the process [26].

While Soxhlet is a widely accepted and efficient method for extraction of oils from a range of materials, its long-time operation needs, special equipment and energy requirements render its application in industrial scale less viable. In this framework, liquid solid extraction was investigated as an alternative and more easily applicable method for bench scale experimenting. N-hexane 95\% was used as solvent. More specifically, separate batches of BSG and SCG were mixed with nhexane, at a solid-to-solvent ratio of 1:10, loaded into the $4 \mathrm{~L}$ reactor, with continuous mechanical stirring at $30^{\circ} \mathrm{C}$ for 4 hours. The insoluble matrix was separated from the solute oil enriched extract with the use of conventional sieve and was dried at $105^{\circ} \mathrm{C}$ for $24 \mathrm{~h}$ so as to remove the residual hexane from the grains. A BÜCHI Rotavapor - R KRvr 65/45, rotary evaporator was used to recover the oil from which the residual moisture and solvent were removed at $105^{\circ} \mathrm{C}$ for $24 \mathrm{~h}$. Dried defatted solids served as reference feedstock for further experimental trials.

\subsection{Chemical pretreatment}

Alkaline pretreatment with $\mathrm{NaOH}$ at $50^{\circ} \mathrm{C}$ was chosen as pretreatment method for SCG and dilute acid pretreatment (dilute $\mathrm{H}_{2} \mathrm{SO}_{4}$ ) was applied for BSG samples at $50^{\circ} \mathrm{C}$ in line with our previous work [20, 24]. In both cases, the severity of pretreatment (concentration of chemicals $(0.5,1 \mathrm{~N})$, pretreatment duration $(5 \mathrm{~h}, 16 \mathrm{~h})$ ) was studied. All experiments were performed thrice.

\subsection{Enzymatic Hydrolysis}

After the oil extraction and chemical pretreatment of separate batches of BSG and SCG, 50:50 (w/w) mixtures of BSG and SCG were prepare aiming to reach the optimum $\mathrm{pH}$ for the enzyme operation without extra addition of chemicals. Enzymatic hydrolysis of defatted and chemically pretreated BSG, SCG or their mixtures was carried out at $50^{\circ} \mathrm{C}$ by adding the cellulase CellicCTec2 (Novozymes, Denmark), which contained 2620 -glucosidase U/mL and $120 \mathrm{FPU} / \mathrm{mL}$. Acid $\left(\mathrm{H}_{2} \mathrm{SO}_{4}\right)$ or alkaline $(\mathrm{NaOH})$ solutions were used to set the $\mathrm{pH}$ at 5.0-5.5, when necessary. The effect of enzyme dosing $(400$ and $800 \mu \mathrm{L} / \mathrm{g}$ cellulose) and time duration (5h, 16h) was studied. All experiments were performed thrice.

\subsection{Ethanol fermentation}


Saccharified hydrolysates were directly subjected to fermentation by $2 \% \mathrm{w} / \mathrm{w}$ Saccharomyces cerevisiae (baker's yeast) at $32^{\circ} \mathrm{C}$ for $24 \mathrm{~h}$. When the fermentation process was completed, slurries were separated to their solid and liquid fractions by centrifugation and were subjected to physico-chemical characterization. Ethanol concentrations were determined in the liquid phase so as to estimate the ethanol yield. The latter was calculated as (Equation 1):

$\mathrm{Y}_{\text {eth }}(\%)=\frac{\text { Ethanol produced }(\mathrm{g})}{\text { Theoretical ethanol maximum }} * 100 \%$

Equation 1

where

Theoretical ethanol maximum $=$ mass of sample $(g) *$ percentage of cellulose $(\% w / w) * 1.11 * 0.51$

taking into account the water hydrolysis (factor 1.11) and the stoichiometric glucose to ethanol conversion during

fermentation (factor 0.51 , the remainder transforms to $\mathrm{CO}_{2}$ ).

\subsection{Analytical methods}

Characterization of raw materials, pretreated and fermented substrates was carried out in accordance with the NREL laboratory analytical protocol by Sluiter et al. [27]. Prior to any quantitative determination, the samples received were centrifugated for $10 \mathrm{~min}$ at $3000 \mathrm{rpm}$ (IEC/Centra CL2). In the solid fraction, total solids, water soluble and volatile solids, lignin (soluble and insoluble), cellulose, hemicellulose and starch were determined. Glucose, total reduced sugars, total organic carbon (TOC), total nitrogen (TN), volatile fatty acids (VFA) as degradation by products and ethanol were assessed in the liquid fraction. Glucose measurement was carried out using a commercial kit (Biosis SA) through the Glucose oxidaseperoxidase method (GOD/PAP). Ethanol concentration was estimated by Ethanol Assay Kit (K-EtOHLQR, Megazymes). Starch was determined as total starch, using AOAC Method 996.11 Total Starch Assay Kit (K-TSTA-100A, Megazymes) and it was measured as glucose released after digestion with thermostable a-amylase and amyloglucisidase. Phenolic compounds were measured by the kit Spectroquant Phenol Test 100856 and VFA quantification was carried out by the Spectroquant Volatile Organinc Acids Test kit (Merck Millipore). Total reducing sugars were determined by the 3,5-dinitrosalicylic acid method [28]. Samples assessment was held in duplicate.

In addition, total organic carbon (TOC) was determined by the Solid Sample Module (SSM-5000A) of the SHIMADZU TOCVCSH (Total organic carbon analyzer), nitrogen (TN) by the KJELDATHERM block digestion unit and the Gerhardt - Vapodest 30s device and $\mathrm{pH}$ by the Mettler-Toledo MPC227 pH/Conductivity Meter.

\section{Results And Discussion}

\subsection{Composition of BSG and SCG}

BSG and SCG are lignocellulosic substrates and are mainly constituted by lignin, cellulose, hemicellulose, proteins and lipids. Their composition varies according to the variety of beans, the harvesting time but also process parameters involved in the brewing of beer or coffee. Table 1 summarizes the composition of the two substrates investigated in this work along with the respective values from literature. The composition of the BSG falls in the ranges determined by Rojas- Chamoro et al., Kemppainen et al. [29, 30], while Mussato et al. [31] have determined higher lignin content up to $27.8 \%$. Regarding SCG, similar composition for cellulose has been reported by Mussatto et al. [32] and Cruz Lopes [33] but with lower hemicellulose fraction (36-39\%) and lignin below 10\%. Higher lignin has been observed in SCG by Kwon et. [34] and Ballesteros et al. [35] which ranged between $23-29 \%$. It must be noted that approximately the $53 \%$ of the BSG and the $59 \%$ of the SCG (dry basis) consists of carbohydrates with the capacity to be degraded into their monomers and undergo fermentation, while their oil content, especially for SCG indicates their capacity for oil extraction and subsequent biodiesel production.

Table 1. Composition of BSG, SCG substrates used 


\begin{tabular}{|c|c|c|c|c|}
\hline & $\begin{array}{c}\text { BSG } \\
\text { (\%dry basis) }\end{array}$ & $\begin{array}{c}\text { Reference } \\
{[30,31,36]}\end{array}$ & $\begin{array}{c}\text { SCG } \\
\text { (\% dry basis) }\end{array}$ & $\begin{array}{c}\text { Reference } \\
{[32-35]}\end{array}$ \\
\hline VS & $97.7 \pm 0.1$ & $95-98.9 \%$ & $99.4 \pm 0.1$ & $97.2-99 \%$ \\
\hline Ash & $2.3 \pm 0.1$ & $1.1-5 \%$ & $0.6 \pm 0.1$ & $1-2.8 \%$ \\
\hline Cellulose & $18.1 \pm 0.8$ & $12-26 \%$ & $7.6 \pm 0.5$ & $7-15.3 \%$ \\
\hline Hemicellulose & $27.9 \pm 2.0$ & $19.2-41.9 \%$ & $42.0 \pm 6.9$ & $28.4-42 \%$ \\
\hline Starch & $4.0 \pm 0.6$ & $0-7.8 \%$ & $0.1 \pm 0.0$ & - \\
\hline AIL & $16.7 \pm 0.5$ & $4-28 \%$ & $20.0 \pm 0.0$ & $0-33.6 \%$ \\
\cline { 1 - 1 } ASL & $1.5 \pm 0.1$ & & $1.5 \pm 0.1$ & \\
\hline Protein & $21.6 \pm 1.3$ & $14.2-35.4 \%$ & $12.9 \pm 0.5$ & $6.7-18 \%$ \\
\hline Oil & $6.0 \pm 0.8$ & $0-13.3 \%$ & $16.9 \pm 0.9$ & $1.9-24 \%$ \\
\hline
\end{tabular}

\subsection{Oil extraction}

The oil recovery of BSG and SCG substrates was evaluated in laboratory scale experiments with the standard Soxhlet method. The ranges of oil recovered were $6.0 \% \pm 0.8 \%$ for BSG and $16.9 \% \pm 0.9 \%$ for SCG on a dry basis. Oil content for BSG falls into the range of literature references (Table 1), while SCG content is among the highest reported. Faulds et al. [37] reported about $5 \%$ lipids in BSG while Kemppainen et al. [30] observed oil contents up to $11.4 \%$. Literature findings for SCG vary from $2.5-6 \%[35,38]$, but also up to $10-15 \%$ [39], depending on the coffee variety and brewing process.

\subsection{Chemical Pretreatment}

Aiming to enlighten the impact of chemical pretreatments on the structure of agro-waste (alkaline pretreatment on SCG and acid pretreatment on BSG), the chemically pretreated substrates were physico-chemically analysed. Table 2 presents the composition of the liquid and solid phase of alkaline pretreated SCG and acid pretreated BSG.

Table 2. Composition of liquid and solid phase of alkaline pretreated SCG and acid pretreated SCG

\begin{tabular}{|c|c|c|c|c|c|c|c|c|c|c|c|c|c|}
\hline \multirow[b]{2}{*}{ SCG } & \multirow[b]{2}{*}{$\begin{array}{c}\mathrm{NaOH} \\
(\mathrm{N})\end{array}$} & \multirow[b]{2}{*}{$\begin{array}{c}\text { Time } \\
\text { (h) }\end{array}$} & \multicolumn{6}{|c|}{ Liquid phase (mg/g SCG) } & \multicolumn{5}{|c|}{ Solid phase (\% d.b.) } \\
\hline & & & Glucose & TRS & VFA & \begin{tabular}{|c|} 
Phenolic \\
compounds
\end{tabular} & TOC & TN & Cellulose & Hemicellulose & Starch & AIL & ASL \\
\hline & 0.5 & 5 & $9.5 \pm 0.7$ & $23.5 \pm 5.7$ & $111.7 \pm 10.4$ & $3.4 \pm 0.9$ & $166.0 \pm 10.8$ & $9.7 \pm 2.3$ & $12.5 \pm 0.3$ & $40.7 \pm 1.5$ & $0.04 \pm 0.03$ & $17.4 \pm 2.3$ & $1.0 \pm 0.2$ \\
\hline & 1 & 5 & $12.3 \pm 0.5$ & $19.8 \pm 2.4$ & $131.6 \pm 11.2$ & $3.2 \pm 0.7$ & $133.4 \pm 11.6$ & $8.3 \pm 1.7$ & $12.8 \pm 1.3$ & $33.9 \pm 1.2$ & $0.07 \pm 0.02$ & $6.6 \pm 1.3$ & $0.9 \pm 0.1$ \\
\hline & 0.5 & 16 & $8.1 \pm 0.3$ & $19.6 \pm 3.1$ & $121.4 \pm 9.7$ & $3.1 \pm 0.4$ & $141.6 \pm 14.0$ & $9.7 \pm 1.9$ & $15.8 \pm 1.7$ & $49.1 \pm 1.9$ & $0.05 \pm 0.01$ & $21.9 \pm 2.0$ & $1.1 \pm 0.3$ \\
\hline \multirow[t]{4}{*}{ BSG } & $\begin{array}{c}\mathrm{H}_{2} \mathrm{SO}_{4} \\
(\mathrm{~N})\end{array}$ & $\begin{array}{c}\text { Time } \\
\text { (h) }\end{array}$ & Glucose & TRS & VFA & $\begin{array}{c}\text { Phenolic } \\
\text { compounds }\end{array}$ & TOC & TN & Cellulose & Hemicellulose & Starch & AIL & ASL \\
\hline & 0.5 & 5 & $0.9 \pm 0.05$ & $1.3 \pm 0.1$ & $15.9 \pm 1.7$ & $0.4 \pm 0.03$ & $57.4 \pm 1.9$ & $6.9 \pm 0.9$ & $12.5 \pm 1.0$ & $6.6 \pm 2.3$ & $0.7 \pm 0.3$ & $42.0+1.9$ & $1.4 \pm 0.2$ \\
\hline & 1 & 5 & $1.8 \pm 0.03$ & $25.8 \pm 1.7$ & $86.2 \pm 2.4$ & $0.3 \pm 0.02$ & $32.9 \pm 1.1$ & $1.0 \pm 0.05$ & $2.3 \pm 0.3$ & $0.2 \pm 0.06$ & $0.0 \pm 0.01$ & $49.1 \pm 2.1$ & $0.5 \pm 0.03$ \\
\hline & 0.5 & 16 & $0.9 \pm 0.02$ & $54.6 \pm 2.4$ & $22.3 \pm 1.8$ & $0.5 \pm 0.02$ & $61.8 \pm 2.2$ & $2.6 \pm 0.8$ & $20.0 \pm 1.6$ & $10.8 \pm 1.3$ & $0.1 \pm 0.01$ & $30.3 \pm 1.6$ & $2.5 \pm 0.2$ \\
\hline
\end{tabular}

During alkaline pretreatment of SCG, the solid degradation ranged from 19.2 to $22.9 \%$, presenting a positive effect for both parameters under investigation. It was revealed that alkaline pretreatment resulted in high lignin degradation (53.7-71.2\%) with moderate degradation of cellulose and hemicellulose. Similarly, Girotto et al. [40], who pretreated SCG under different $\mathrm{NaOH}$ loadings only achieved a $4.8 \%$ hemicellulose degradation with $7.5 \% \mathrm{NaOH}$, but similar hemicellulose degradations with $2 \% \mathrm{w} / \mathrm{w} \mathrm{NaOH}$ which increased as the $\mathrm{NaOH}$ concentration increased. They also reported increased lignin removal with increased $\mathrm{NaOH}$ concentration when pretreating SCG. 
Delignification by-products (phenolic compounds and volatile fatty acids) were also present in all prehydrolysates, as a side effect of the pretreatment method and could be attributed to the lignin degradation. Under alkaline conditions, phenolic compounds from the degradation of lignin and volatile fatty acids (VFA) from the hydrolyzed acetyl groups of hemicellulose are released [41]. Such compounds have been reported to act inhibitory to downstream biochemical processes, causing deterrence of cellulolytic enzymes and inhibition of fermenting microorganisms [42, 43]. A pretreatment method is efficient when it accomplishes high delignification and simultaneous alleviation of inhibition problems. Regarding the utilized yeast S. cerevisiae, it has been reported that VFA concentration above $6 \mathrm{~g} / \mathrm{L}$ can inhibit ethanol fermentation, causing up to $100 \%$ inhibition for $10 \mathrm{~g} / \mathrm{L}$ (inhibition accessed as reduction in cell mass) [44]. Similarly, according to Colombi et al. [45] , phenolic compounds at a concentration between $0.1-1 \mathrm{~g} / \mathrm{L}$ can be toxic for S. cerevisiae causing up to $46 \%$ drop in ethanol yield. Yang et al. (2016) also reported that $1.5 \mathrm{~g} / \mathrm{L}$ of phenols can cause $5.4 \%$ decrease in ethanol yield, while higher inhibitory levels are reported by Gu et al. (2019) (3-5g/L). Phenolic compounds and VFA concentrations fluctuate according to the degradation of lignin and hemicellulose respectively, in accordance with previous researches [23]. Similar concentrations of degradation products in the liquid phase have also been studied by Passadis et al. [24], although the concentration of glucose reported was lower (1.8-4.9 mg/g SCG). Increase of the pretreatment time did not particularly differentiate polysaccharides degradation but slightly increased the inhibitors concentrations in pretreated liquors. The phenolic compounds detected after alkaline pretreatment of SCG were below $300 \mathrm{mg} / \mathrm{L}$ and thus below the ones reported by Mussato et al. and M. FernandezDelgado et al. [31, 46], probably due to the lower delignification percentages achieved. Hence, they are not expected to induce severe inhibition to microbial growth. On the other hand, high VFA concentrations were detected in individual SCG (10.5 \pm $0.9 \mathrm{~g} / \mathrm{L}$ ) prehydrolysates, that fluctuate within the potentially toxic levels for $\mathrm{S}$. cerevisiae.

Dilute acid pretreatment on BSG, on the other hand, did not affect the lignin structure, while cellulose and hemicellulose degradation reached $89 \%$ and $99 \%$ respectively when $1 \mathrm{~N} \mathrm{H}_{2} \mathrm{SO}_{4}$ was used. In other words, elevated concentration of $\mathrm{H}_{2} \mathrm{SO}_{4}$, from $0.5 \mathrm{~N}$ to $1 \mathrm{~N}$, while it degraded more acid soluble lignin and hemicellulose, it was linked with significantly higher accumulation of VFA compared to the other acid pretreatment levels examined. The high VFA concentrations that were detected in individual BSG $(8.3 \pm 0.8 \mathrm{~g} / \mathrm{L})$ prehydrolysates could be considered toxic for S. cerevisiae. In general, the degradation results are in accordance with our previous study [20] where low solubilization of BSG, low lignin degradation

and high polysaccharides degradation were observed when acid pretreatment was applied on BSG. Similar results have also been reported elsewhere in literature. Rojas-Chamorro et al. [29] indicated that pretreatment of BSG with $\mathrm{H}_{2} \mathrm{SO}_{4}$ resulted in high hemicellulose degradation between $70-89.4 \%$ and lower toxic compounds concentration. Dimos et al. [47] and Carvalheiro et al. [48] have also concluded that the dilute acid pretreatment results in the hemicellulose hydrolysis. Despite the high carbohydrates degradation, free sugars were not released in the liquid phase, implying that the depolymerization of carbohydrates was partial and did not result in monomeric sugars.

\subsection{Ethanol production}

BSG, SCG and their mixtures were examined as for their bioethanol potential via a biochemical conversion route. Table 3 presents the characteristics of the liquid phase of the fermentation broth and Table 4 presents the efficiencies achieved in terms of structural components degradation and ethanol yield.

Table 3. Characteristics of liquid phase of fermentation broth 


\begin{tabular}{|c|c|c|c|c|c|c|c|c|c|c|c|}
\hline \multirow{3}{*}{ Substrate } & \multicolumn{4}{|c|}{ Conditions } & \multirow{2}{*}{\multicolumn{7}{|c|}{$\begin{array}{c}\text { Results } \\
\text { Liquid phase } \\
\text { (mg/g) }\end{array}$}} \\
\hline & \multicolumn{2}{|c|}{ Pretreatment } & \multicolumn{2}{|c|}{ Enzymatic Hydrolysis } & & & & & & & \\
\hline & $\begin{array}{c}\text { Concentration } \\
\text { (N) }\end{array}$ & $\begin{array}{l}\text { Time } \\
\text { (h) }\end{array}$ & $\begin{array}{l}\text { Loading } \\
(\mu \mathrm{L} / \mathrm{g} \\
\text { cellulose })\end{array}$ & \begin{tabular}{|l|} 
Time \\
(h)
\end{tabular} & Glucose & TRS & VFA & $\begin{array}{l}\text { Phenolic } \\
\text { compounds }\end{array}$ & TOC & TN & Ethanol \\
\hline SCG & 0.5 & 5 & 400 & 5 & $5.3 \pm 0.7$ & $29.0 \pm 2.1$ & $120.2 \pm 10.2$ & $1.0 \pm 0.03$ & $154.1 \pm 11.1$ & $14.2 \pm 0.6$ & $10.3 \pm 0.6$ \\
\hline BSG & 0.5 & 5 & 400 & 5 & $0.8 \pm 0.03$ & $11.2 \pm 0.7$ & $17.1 \pm 9.7$ & $0.3 \pm 0.01$ & $94.3 \pm 9.7$ & $5.3 \pm 0.7$ & $43.8 \pm 1.5$ \\
\hline SCG/BSG & 0.5 & 5 & 400 & 5 & $2.4 \pm 0.01$ & $49.7 \pm 4.7$ & $44.7 \pm 11.1$ & $1.1 \pm 0.03$ & $121.3 \pm 12.2$ & $6.7 \pm 0.3$ & $25.2 \pm 1.7$ \\
\hline SCG/BSG & 0.5 & 16 & 400 & 5 & $3.8 \pm 0.04$ & $70.7 \pm 3.2$ & $76.5 \pm 8.6$ & $1.5 \pm 0.02$ & $122.5 \pm 9.7$ & $7.1 \pm 1.1$ & $46.5 \pm 2.1$ \\
\hline SCG/BSG & 0.5 & 5 & 400 & 16 & $2.5 \pm 0.04$ & $46.1 \pm 4.3$ & $61.5 \pm 5.3$ & $1.0 \pm 0.01$ & $101.9 \pm 8.3$ & $5.4 \pm 0.6$ & $50.4 \pm 1.9$ \\
\hline SCG/BSG & 0.5 & 5 & 800 & 5 & $2.0 \pm 0.03$ & $51.8 \pm 7.7$ & $62.3 \pm 6.2$ & $1.1 \pm 0.02$ & $105.3 \pm 7.7$ & $5.7 \pm 0.5$ & $62.0 \pm 1.6$ \\
\hline SCG/BSG & 1 & 5 & 400 & 5 & $1.5 \pm 0.02$ & $64.7 \pm 5.7$ & $58.9 \pm 5.9$ & $1.2 \pm 0.04$ & $101 \pm 5.3$ & $5.6 \pm 0.8$ & $34.9 \pm 1.2$ \\
\hline
\end{tabular}

Table 4. Degradation efficiencies of structural components and ethanol yields achieved

\begin{tabular}{|c|c|c|c|c|c|c|c|c|c|c|c|}
\hline \multirow{3}{*}{ Substrate } & \multicolumn{4}{|c|}{ Conditions } & \multicolumn{7}{|c|}{ Results } \\
\hline & \multicolumn{2}{|c|}{ Pretreatment } & \multicolumn{2}{|c|}{ Enzymatic Hydrolysis } & \multicolumn{6}{|c|}{$\%$ degradation } & \multirow{2}{*}{\begin{tabular}{|c} 
Ethanol \\
Yield \\
$(\%)$
\end{tabular}} \\
\hline & $\begin{array}{c}\text { Concentration } \\
\text { (N) }\end{array}$ & $\begin{array}{c}\text { Time } \\
\text { (h) }\end{array}$ & $\begin{array}{c}\text { Loading } \\
(\mu \mathrm{L} / \mathrm{g} \\
\text { cellulose) }\end{array}$ & Time (h) & TS & Cellulose & Hemicellulose & Starch & AIL & ASL & \\
\hline SCG & 0.5 & 5 & 400 & 5 & $16.4 \pm 0.7$ & $15.3 \pm 0.3$ & $14.9 \pm 2.7$ & $45.1 \pm 2.2$ & $30.7 \pm 2.2$ & $68.4 \pm 2.2$ & $19.9 \pm 1.8$ \\
\hline BSG & 0.5 & 5 & 400 & 5 & $15.1 \pm 0.7$ & $21.3 \pm 1.1$ & $27.8 \pm 2.5$ & $87.9 \pm 7.7$ & $0.4 \pm 1.3$ & $4.2 \pm 2.1$ & $39.5 \pm 2.3$ \\
\hline SCG/BSG & 0.5 & 5 & 400 & 5 & $27.2 \pm 0.9$ & $41.3 \pm 2.8$ & $39.1 \pm 5.6$ & $23.5 \pm 1.7$ & $2.0 \pm 0.1$ & $20.5 \pm 1.7$ & $31.4 \pm 1.4$ \\
\hline SCG/BSG & 0.5 & 16 & 400 & 5 & $14.1 \pm 0.3$ & $28.8 \pm 2.2$ & $61.3 \pm 4.8$ & $48.5 \pm 1.7$ & $17.3 \pm 1.3$ & $12.1 \pm 1.5$ & $51.6 \pm 2.1$ \\
\hline SCG/BSG & 0.5 & 5 & 400 & 16 & $26.9 \pm 1.2$ & $24.8 \pm 2.2$ & $33.3 \pm 3.2$ & $95.1 \pm 2.1$ & $3.5 \pm 0.9$ & $1.7 \pm 0.1$ & $44.3 \pm 1.1$ \\
\hline SCG/BSG & 0.5 & 5 & 800 & 5 & $26.3 \pm 2.1$ & $35.5 \pm 1.9$ & $49.0 \pm 2.7$ & $92.8 \pm 2.1$ & $0.8 \pm 0.1$ & $17.8 \pm 1.5$ & $57.3 \pm 2.7$ \\
\hline SCG/BSG & 1 & 5 & 400 & 5 & $23.7 \pm 2.3$ & $24.7 \pm 2.0$ & $46.8 \pm 3.7$ & $95.0 \pm 2.0$ & $11.5 \pm 1.1$ & $16.2 \pm 1.1$ & $10.0 \pm 1.9$ \\
\hline
\end{tabular}

The alkaline pretreatment, enzymatic hydrolysis and ethanolic fermentation of SCG achieved moderate degradation degrees of cellulose $(15.3 \pm 0.3 \%)$, and were followed by low ethanol yields $(19.9 \pm 1.8 \%)$. In literature, defatted SCG have been utilised for bioethanol production providing a range of operational configurations and conditions and thus a range of efficiencies [25]. Alkaline pretreatment is often suggested as the most suitable pretreatment method, given the milder operational conditions, the lower environmental impact, the lower corrosivity of $\mathrm{NaOH}$ solutions and the higher delignification yields [24].

Although in literature high ethanol yields for BSG have been reported [49], they significantly vary depending on the processes applied. In general, it is well established that harsh pretreatment conditions favour ethanol production [20], but at the same time they induce severe cost and safety issues.

From Table 4, it is evident that in almost all cases the application of mixtures of BSG and SCG provided higher ethanol yields (40.0-57.3\%) than each substrate alone (19.9\% for SCG and 39.5\% for BSG). Furthermore, the degradation of starch is almost complete and the degradation of hemicellulose is significantly increased. Thus, the synergistic effect of co-treatment is obvious.

Several references in literature report better performance of mixtures, produced from different combinations of biomass feedstocks against plain batches, after fermentation with different microorganisms [4], although no paper has been 
published using mixtures of BSG and SCG as substrates. Chen et al. [50] processed corn stover and corn at a 1:1 ratio with acid pretreatment and fermentation with Z. mobilis at $30 \%$ solid loading, and achieved up to $94.1 \mathrm{~g} / \mathrm{L}$ ethanol $(74.2 \%$ theoretical yield), against $0.89 \mathrm{~g} / \mathrm{L}$ for corn stover alone. Erdei et al. [9], after simultaneous fermentation with ordinary baker's yeast of separately pretreated mixtures of wheat straw and wheat meal, reported an increased theoretical ethanol yield (up to $99 \%$ ) compared to those obtained by either of the substrates alone (68\% and $91 \%$ respectively). In another study, Nguyen et al. [5] subjected different mixtures of coffee bean husks, cassava stems and coconut coir to simultaneous saccharification and fermentation and detected up to $12 \mathrm{~g} / \mathrm{L}$ ethanol after $24 \mathrm{~h}$ (47\% ethanol theoretical yield). Mixtures of ricotta whey and sugarcane bagasse produced $49.7 \mathrm{~g} / \mathrm{L}$ ethanol after fermentation with Kluyveromyces marxianus, which was higher than the ones produced from sugarcane baggase alone [7]. Moreover, acid pretreated residues from sugarcane industry (straw, bagasse, tops) when were studied in mixtures as for their bioethanol potential achieved up to $25 \%$ higher ethanol yield and $55 \%$ higher enzymatic conversion than bagasse alone [8]. Also, Imamoglu et al. [51] by combinedly pretreating mixtures of rice hulls (70\%) and cotton stalks (30\%) at different ratios and by subsequent fermentation with E. coli produced $20.7 \mathrm{~g} / \mathrm{L}$ ethanol compared to $7.2 \mathrm{~g} / \mathrm{L}$ for corn stalks alone. All the references above resulted in comparable or higher ethanol yields than the present study.

\subsection{Selection of conversion pathway based on ethanol production cost}

As optimization parameter of the bioethanol production process, the bioethanol production cost was set, since the ethanol yields should be considered taking into account the consumption of energy and additives.

According to Ge et al. [52], the cellulosic ethanol production cost is the sum of 5 parameters: water, energy, enzymes bacteria and chemicals. The total bioethanol production cost includes a fixed fraction associated with labor, maintenance, insurance etc. and a variable fraction related to additives consumption. The latter could be described as (Equation 2):

$C_{\text {production }}=C_{\text {Energy }}+C_{\text {Water }}+C_{\text {Chemical }}+C_{\text {Enzyme }}+C_{\text {Bacteria }}$

Equation 2

The energy cost includes two aspects: the respective cost of the chemical pretreatment and of the enzymatic hydrolysis and fermentation processes. Mafe et al. [53] developed a model in order to estimate the energy demands during the acidic pretreatment of lignocellulosic biomass. It was proved that the highest energy requirements are related to biomass heating prior to its pretreatment, while the energy demands for reactions and maintenance could be neglected. Staying in line with this approach, the energy needs were estimated by the following equation (Equation 3):

$$
Q_{\text {heating }}=m_{w} \int_{T_{o}}^{T_{H}} C_{p_{w}} d T+m_{b} \int_{T_{o}}^{T_{H}} C_{p_{b}} d T+m_{a} \overline{C_{p_{a}}}\left(T_{H}-T_{o}\right) \quad \text { Equation } 3
$$

$\mathrm{Cp}$ is the specific heat capacity $\left(\mathrm{cal} / \mathrm{kg} /{ }^{\circ} \mathrm{C}\right) ; \mathrm{m}_{\mathrm{b}}, \mathrm{m}_{\mathrm{w}}, \mathrm{m}_{\mathrm{a}}$, is the mass $(\mathrm{kg})$ of biomass, water and chemicals respectively; $\mathrm{T}_{H}$ is the processes' temperature $\left({ }^{\circ} \mathrm{C}\right)$ and $\mathrm{T}_{0}$ is the ambient temperature of $25^{\circ} \mathrm{C}$.

Given the narrow range of the operational temperature $\left(20^{\circ} \mathrm{C}-50^{\circ} \mathrm{C}\right)$, the specific heat capacities of water and feedstocks were considered constant. The SCG and BSG specific heat capacities were measured according to the ASTM D2766 - 95.

The heat loss during the process was calculated using the following equation (Equation 4) in accordance with Mafe et al. approach [53].

$$
Q_{\text {lost }}=0.05 \times\left(\frac{\tau_{\text {maintenance }}}{\tau_{\text {heating }}}\right) \times Q_{\text {heating }} \quad \text { Equation } 4
$$

where that $\tau_{\text {maintenace }}$ is the residence time for the process and $\tau_{\text {heating }}$ is the heating up time. 
Water consumption rate is a function of the selected solid loading in the process. Chemical compounds are consumed during the pretreatment process (alkaline and acidic) and as additives for $\mathrm{pH}$ correction prior to enzymatic hydrolysis. The price of chemicals depends on the pretreatment type. A cellulolytic enzymatic formulation is utilised for the enzymatic hydrolysis and bacteria/yeast for ethanolic fermentation. Their unit prices are functions of saccharification and fermentation operational conditions.

Table 5. Values adopted for the construction of the model for bioethanol production cost

\begin{tabular}{|l|c|}
\hline Parameter & Value \\
\hline $\mathrm{C}_{\mathrm{p}, \mathrm{SCG}}$ & $0.63 \mathrm{cal} / \mathrm{g} /{ }^{\circ} \mathrm{C}$ \\
\hline $\mathrm{c}_{\mathrm{p}, \mathrm{BSG}}$ & $0.83 \mathrm{cal} / \mathrm{g} /{ }^{\circ} \mathrm{C}$ \\
\hline $\mathrm{C}_{\mathrm{p}, \text { Water }}$ & $1.00 \mathrm{cal} / \mathrm{g} /{ }^{\circ} \mathrm{C}$ \\
\hline $\mathrm{C}_{\mathrm{p}, \mathrm{NaOH}}$ & $0.35 \mathrm{cal} / \mathrm{g} /{ }^{\circ} \mathrm{C}$ \\
\hline $\mathrm{c}_{\mathrm{p}, \mathrm{H} 2 \mathrm{SO} 4}$ & $0.22 \mathrm{cal} / \mathrm{g} /{ }^{\circ} \mathrm{C}$ \\
\hline Unit prices & \\
\hline $\mathrm{NaOH}$ & $0.35 € / \mathrm{kg}$ \\
\hline $\mathrm{H}_{2} \mathrm{SO}{ }_{4}$ & $0.25 € / \mathrm{kg}$ \\
\hline Water & $0.83 € / \mathrm{m}^{3}$ \\
\hline CellicCTec2 & $1.00 € / \mathrm{L}$ \\
\hline Yeast & $1.20 € / \mathrm{kg}$ \\
\hline Energy & $0.0647 € / \mathrm{kWh}$ \\
\hline
\end{tabular}

According to the experimental results, the mass flows were set up and the ethanol production cost for each case was estimated. Table 6 presents the estimated ethanol production costs for the different scenarios. Scenario 1 considered separated and independent production line for each substrate, while scenarios 2 to 6 separate oil extraction and chemical pretreatment and subsequent treatment as a mixture.

Table 6. Estimated ethanol production costs for the different mixtures of BSG and SCG

\begin{tabular}{|c|c|c|c|c|c|c|}
\hline & & \multicolumn{4}{|c|}{ Conditions } & \multirow{3}{*}{$\begin{array}{c}\text { Ethanol production cost } \\
(€ / \mathrm{kg})\end{array}$} \\
\hline & \multirow{2}{*}{ Substrate } & \multicolumn{2}{|c|}{ Chemical Pretreatment } & \multicolumn{2}{|c|}{ Enzymatic Hydrolysis } & \\
\hline & & Concentratio & $\begin{array}{c}\text { Time } \\
\text { (h) }\end{array}$ & $\begin{array}{c}\text { Loading } \\
(\mu \mathrm{L} / \mathrm{g} \text { cellulose })\end{array}$ & $\begin{array}{c}\text { Time } \\
\text { (h) }\end{array}$ & \\
\hline \multirow[t]{2}{*}{ Scenario 1} & SCG & 0.5 & 5 & 400 & 5 & \multirow[t]{2}{*}{9.31} \\
\hline & BSG & 0.5 & 5 & 400 & 5 & \\
\hline Scenario 2| & $\mathrm{SCG} / \mathrm{BSG}$ & 0.5 & 5 & 400 & 5 & 7.32 \\
\hline Scenario 3 & SCG/BSG & 0.5 & 16 & 400 & 5 & 4.20 \\
\hline Scenario 4 & SCG/BSG & 0.5 & 5 & 400 & 16 & 3.88 \\
\hline Scenario 5 & $\mathrm{SCG} / \mathrm{BSG}$ & 0.5 & 5 & 800 & 5 & 3.89 \\
\hline Scenario 6 & $\mathrm{SCG} / \mathrm{BSG}$ & 1 & 5 & 400 & 5 & 7.15 \\
\hline
\end{tabular}

Fig. 1 presents the ethanol production cost for each experimental set-up along with the respective break down of the cost.

From Fig. 1, it is evident that the contribution of water cost is very low for all cases since it accounts for just 3-4\%, while the yeast contributes $10-12 \%$ to the total cost. On the contrary, energy, chemicals and enzyme cost are the major contributors in the final ethanol cost, as was anticipated. Scenario 1 presents the highest cost and this fact validates the advantage of the co-treatment of SCG with BSG. In this scenario, the cost of chemicals was over $50 \%$, since chemicals are used for both the pretreatment and the $\mathrm{pH}$ regulation before enzymatic hydrolysis. Scenarios 4 (SCG/BSG mixture, chemical pretreatment $(0.5 \mathrm{~N}, 5 \mathrm{~h})$, enzymatic hydrolysis $(400 \mu \mathrm{L} / \mathrm{g}$ cellulose, $16 \mathrm{~h})$ ) and 5 (SCG/BSG mixture, chemical pretreatment $(0.5 \mathrm{~N}, 5 \mathrm{~h})$, enzymatic hydrolysis $(800 \mu \mathrm{L} / \mathrm{g}$ cellulose, $5 \mathrm{~h}))$ led to the lowest ethanol production cost $(3.9 € / \mathrm{kg})$. 


\subsection{Sensitivity analysis}

In order to determine the critical factors in the present study, the effect of the assumed unit prices on the optimum results was studied. The factors that were considered are: (1) $\mathrm{NaOH}$ price, (2) $\mathrm{H}_{2} \mathrm{SO}_{4}$ price, (3) water price, (4) enzyme price, (5) yeast price and (6) energy price. They were altered by $\pm 20 \%$ to assess the impact.

In Fig. 2, it is obvious that the cost of bioethanol has non-linear correlations with the six factors. The minimum unit bioethanol cost is noted when the enzyme cost is decreased by $20 \%$ under the operational conditions of Scenario 5 , that includes pretreatment with chemicals concentration $0.5 \mathrm{~N}$ for $5 \mathrm{~h}$ and enzymatic hydrolysis with elevated enzyme loading $(800 \mu \mathrm{L} / \mathrm{g}$ cellulose $)$ for $5 \mathrm{~h}$. It is noted that for scenario 5 , enzyme cost has the highest impact on ethanol production cost, while the rest of the parameters (apart from water) present the same weighted impact. Enzyme cost is also the most significant parameter when studying Scenario 4, but its impact is closer to the other parameters.

\subsection{Bench scale}

Applications of mixed lignocellulosic biomass have shown that combined substrates can achieve comparable or even greater fermentation efficiencies than single substrates. However, these results are based on laboratory evaluations and ethanol production from lignocellulosic mixtures is still an underdeveloped practice. Thus, the optimum scenarios were upscaled from laboratory conditions to bench scale.

By solid-liquid extraction, the oil recovered amounted to $4.4 \% \pm 0.8 \%$ for BSG and to $10.2 \% \pm 0.6 \%$ for SCG. In other words, the oil content recovery efficiencies were $73.6 \%$ and $60.2 \%$ for BSG and SCG respectively. These efficiencies could be assumed satisfactory and thus, the scheme examined could be incorporated within a biorefinery that aims at the production of biodiesel. In the study of Mallen and Najdanovic-Visak [18], the oil extracted from BSG was converted by the use of sulfuric acid to biodiesel with an efficiency of $83.3 \%$ through a single-step transesterification, while the transesterification yields that have been reported in literature for SCG oil were higher than $56 \%$ and in some cases they even reach $100 \%$. Such yields are comparable with those that have been reported for other vegetable oils [25].

The defatted substrates were treated according to the operational conditions of Scenarios 4 (SCG/BSG mixture, chemical pretreatment $(0.5 \mathrm{~N}, 5 \mathrm{~h})$, enzymatic hydrolysis $(400 \mu \mathrm{L} / \mathrm{g}$ cellulose, $16 \mathrm{~h}))$ and 5 (SCG/BSG mixture, chemical pretreatment $(0.5 \mathrm{~N}, 5 \mathrm{~h})$, enzymatic hydrolysis $(800 \mu \mathrm{L} / \mathrm{g}$ cellulose, $5 \mathrm{~h}))$ in the $4 \mathrm{~L}$ mechanically agitated reactors. The ethanol yields achieved reached up to $79.7 \%$ and $84.7 \%$ respectively.

Hence, the upscaling led to a significant increase of ethanol yield in both cases. This fact can be mainly attributed to the mechanical stirring, which in turn led to a more efficient action and diffusion of chemicals and enzymes. The increased ethanol yields, as expected, led to a further decrease of ethanol production cost reaching $2.13 € / \mathrm{kg}$ and $2.63 € / \mathrm{kg}$ for scenarios 4 and 5 , respectively.

Thus, an integrated multi-feedstock biorefinery that utilizes both SCG and BSG in combination as feedstocks producing both used oil suitable for biodiesel production and bioethanol could stand as a promising alternative. Fig. 3 presents the basic mass flows of the proposed biorefinery applying the operational conditions of Scenario 4.

\section{Conclusions And Further Perspective}

SCG and BSG, biowaste streams from beer and coffee industries, are feedstocks with high perspectives for valorization given their abundance, the simplicity of their collection network (point sources) and their composition. In this context, a multi-feedstock biorefinery that would use and upgrade these feedstocks to added value products was set as main goal of this study. In this study, the technical feasibility of oil extraction and ethanol production was validated and optimized in both laboratory and bench scale experiments. The ethanol production process unit included alkaline pretreatment of SCG and 
dilute acid pretreatment of BSG, neutralization of the chemically pretreated substrates by mixing them, enzymatic hydrolysis and ethanolic fermentation. The co-treatment of the two substrates proved to be advantageous compared with the independent parallel treatments, given the savings from the neutralization chemicals and possible emerging synergies during bioprocessing. The production cost of ethanol was calculated and set as a driver for the choice of the operational conditions. Scenarios 4 (SCG/BSG mixture, chemical pretreatment $(0.5 \mathrm{~N}, 5 \mathrm{~h})$, enzymatic hydrolysis $(400 \mu \mathrm{L} / \mathrm{g}$ cellulose, $16 \mathrm{~h})$ ) and 5 (SCG/BSG mixture, chemical pretreatment ( $0.5 \mathrm{~N}, 5 \mathrm{~h})$, enzymatic hydrolysis ( $800 \mu \mathrm{L} / \mathrm{g}$ cellulose, $5 \mathrm{~h})$ ) led to the lowest ethanol production cost $(3.9 € / \mathrm{kg})$. From the sensitivity analysis, it was noted that the bioethanol unit price has nonlinear correlations with the unit prices of the additives (chemicals, enzymes, yeast), with the enzyme cost being the most significant parameter. The upscaling of the process proved the technical feasibility of oil extraction with high efficiencies and led to an increase of ethanol yield, with subsequent decrease of its production cost.

Thus, the perspective of a multi-feedstock biorefinery that would valorise SCG and BSG producing oil and bioethanol seems to be promising. Nevertheless, the ethanol production cost is still elevated if the market price of cellulosic ethanol is taken into account. Therefore, in future work, this study could be extended to take into account technical issues such as minimization and/or recycling of enzymes, increase of solids loading and valorization of the fermentation broth via anaerobic digestion. In terms of sustainability, carbon and water footprint, energy integration, recycle of waste should also be considered. The outmost goal could be set as the design of a sustainable supply chain for the multi-feedstock biorefinery that could be simultaneously optimized in terms of its economic and sustainability performance.

\section{Declarations}

Funding: The authors acknowledge funding through LIFE CIRCforBIO (LIFE Ref. No: LIFE18 CCM/GR/001180) project for supporting this work.

\section{Conflicts of interest/Competing interests:}

The authors have no conflicts of interest to declare that are relevant to the content of this article.

Availability of data and material (data transparency): Not applicable

Code availability (software application or custom code): Not applicable

\section{Authors' contributions:}

Conceptualization: Sofia Mai, Elli Maria Barampouti

Methodology: Sofia Mai, Elli Maria Barampouti

Formal analysis and investigation: Christos Grammatikos, Vasileia Stoumpou,

Writing - original draft preparation: Vasileia Stoumpou,

Writing - review and editing: Sofia Mai, Elli Maria Barampouti

Funding acquisition: Maria Loizidou, Dimitris Malamis

Supervision: Dimitris Malamis

\section{References}

1. Stenmarck, A., Jensen, C., Quested, T., Moates, G.: Estimates of European food waste levels. (2018) 
2. Procentese, A., Raganati, F., Olivieri, G., Russo, M.E., De La Feld, M., Marzocchella, A.: Agro Food Wastes and Innovative Pretreatments to Meet Biofuel Demand in Europe. Chem. Eng. Technol. 42, 954-961 (2019).

https://doi.org/10.1002/ceat.201800459

3. Dos Santos, L.V., De Barros Grassi, M.C., Gallardo, J.C.M., Pirolla, R.A.S., Calderón, L.L., De Carvalho-Netto, O.V., Parreiras, L.S., Camargo, E.L.O., Drezza, A.L., Missawa, S.K., Teixeira, G.S., Lunardi, I., Bressiani, J., Pereira, G.A.G.: SecondGeneration Ethanol: The Need is Becoming a Reality. Ind. Biotechnol. 12, 40-57 (2016). https://doi.org/10.1089/ind.2015.0017

4. Oke, M.A., Annuar, M.S.M., Simarani, K.: Mixed Feedstock Approach to Lignocellulosic Ethanol Production-Prospects and Limitations. Bioenergy Res. 9, 1189-1203 (2016). https://doi.org/10.1007/s12155-016-9765-8

5. Nguyen, Q.A., Yang, J., Bae, H.J.: Bioethanol production from individual and mixed agricultural biomass residues. Ind. Crops Prod. 95, 718-725 (2017). https://doi.org/10.1016/j.indcrop.2016.11.040

6. Baral, N.R., Davis, R., Bradley, T.H.: Supply and value chain analysis of mixed biomass feedstock supply system for lignocellulosic sugar production. Biofuels, Bioprod. Biorefining. 13, 635-659 (2019). https://doi.org/10.1002/bbb.1975

7. Ferreira, P.G., da Silveira, F.A., dos Santos, R.C.V., Genier, H.L.A., Diniz, R.H.S., Ribeiro, J.I., Fietto, L.G., Passos, F.M.L., da Silveira, W.B.: Optimizing ethanol production by thermotolerant Kluyveromyces marxianus CCT 7735 in a mixture of sugarcane bagasse and ricotta whey. Food Sci. Biotechnol. 24, 1421-1427 (2015). https://doi.org/10.1007/s10068015-0182-0

8. Pereira, S.C., Maehara, L., Machado, C.M.M., Farinas, C.S.: $2 \mathrm{G}$ ethanol from the whole sugarcane lignocellulosic biomass. Biotechnol. Biofuels. 8, 1-16 (2015). https://doi.org/10.1186/s13068-015-0224-0

9. Erdei, B., Barta, Z., Sipos, B., Réczey, K., Galbe, M., Zacchi, G.: Research ethanol production from mixtures of wheat straw and wheat meal. Biotechnol. Biofuels. 3, 1-9 (2010). https://doi.org/10.1186/1754-6834-3-16

10. Oreopoulou, V., Russ, W.: Integrating Safety and Environment Knowledge Into Food Studies towards European Sustainable Development Utilization of By-Products and Treatment of Waste in the Food Industry Utilization of ByProducts and Treatment of. (2007)

11. Gupta, M., Abu-Ghannam, N., Gallaghar, E.: Barley for brewing: Characteristic changes during malting, brewing and applications of its by-products. Compr. Rev. Food Sci. Food Saf. 9, 318-328 (2010). https://doi.org/10.1111/j.15414337.2010.00112.x

12. Stylianou, M., Agapiou, A., Omirou, M., Vyrides, I., loannides, I.M., Maratheftis, G., Fasoula, D.: Converting environmental risks to benefits by using spent coffee grounds (SCG) as a valuable resource. Environ. Sci. Pollut. Res. 25, 3577635790 (2018). https://doi.org/10.1007/s11356-018-2359-6

13. Fărcaş, A.C., Socaci, S.A., Mudura, E., Dulf, F.V., Vodnar, D.C., Tofană, M., Salanță, L.C.: Exploitation of Brewing Industry Wastes to Produce Functional Ingredients. In: Kanauchi, M. (ed.) Brewing technology. IntechOpen (2017)

14. Mata, T.M., Martins, A.A., Caetano, N.S.: Bio-refinery approach for spent coffee grounds valorization. Bioresour. Technol. 247, 1077-1084 (2018). https://doi.org/10.1016/j.biortech.2017.09.106

15. Massaya, J., Prates Pereira, A., Mills-Lamptey, B., Benjamin, J., Chuck, C.J.: Conceptualization of a spent coffee grounds biorefinery: A review of existing valorisation approaches. Food Bioprod. Process. 118, 149-166 (2019). https://doi.org/10.1016/j.fbp.2019.08.010

16. Najdanovic-Visak, V., Lee, F.Y.L., Tavares, M.T., Armstrong, A.: Kinetics of extraction and in situ transesterification of oils from spent coffee grounds. J. Environ. Chem. Eng. 5, 2611-2616 (2017). https://doi.org/10.1016/j.jece.2017.04.041

17. Park, J., Kim, B., Lee, J.W.: In-situ transesterification of wet spent coffee grounds for sustainable biodiesel production. Bioresour. Technol. 221, 55-60 (2016). https://doi.org/10.1016/j.biortech.2016.09.001

18. Mallen, E., Najdanovic-Visak, V.: Brewers' spent grains: Drying kinetics and biodiesel production. Bioresour. Technol. Reports. 1, 16-23 (2018). https://doi.org/10.1016/j.biteb.2018.01.005 
19. Salimi, E., Taheri, M.E., Passadis, K., Novacovic, J., Barampouti, E.M., Mai, S., Moustakas, K., Malamis, D., Loizidou, M.: Valorisation of restaurant food waste under the concept of a biorefinery. Biomass Convers. Biorefinery. (2020). https://doi.org/10.1007/s13399-020-00613-4

20. Kavalopoulos, M., Stoumpou, V., Christofi, A., Mai, S., Barampouti, E.M., Moustakas, K., Malamis, D., Loizidou, M.: Sustainable valorisation pathways mitigating environmental pollution from brewers' spent grains. Environ. Pollut. 270, 116069 (2021). https://doi.org/10.1016/j.envpol.2020.116069

21. Jin, L.S., Salimi, M.N., Kamal, S.Z.: Optimization of Pretreatment and Enzymatic Hydrolysis of Spent Coffee Ground for the Production of Fermentable Sugar. IOP Conf. Ser. Mater. Sci. Eng. 743, (2020). https://doi.org/10.1088/1757$899 X / 743 / 1 / 012030$

22. Brodeur-Campbell, M., Klinger, J., Shonnard, D.: Feedstock mixture effects on sugar monomer recovery following dilute acid pretreatment and enzymatic hydrolysis. Bioresour. Technol. 116, 320-326 (2012).

https://doi.org/10.1016/j.biortech.2012.03.090

23. Mussatto, S.I., Machado, E.M.S., Carneiro, L.M., Teixeira, J.A.: Sugars metabolism and ethanol production by different yeast strains from coffee industry wastes hydrolysates. Appl. Energy. 92, 763-768 (2012). https://doi.org/10.1016/j.apenergy.2011.08.020

24. Passadis, K., Fragoulis, V., Stoumpou, V., Novakovic, J., Barampouti, E.M., Mai, S., Moustakas, K., Malamis, D., Loizidou, M.: Study of Valorisation Routes of Spent Coffee Grounds. Waste and Biomass Valorization. 11, 5295-5306 (2020). https://doi.org/10.1007/s12649-020-01096-0

25. Battista, F., Barampouti, E.M., Mai, S., Bolzonella, D., Malamis, D., Moustakas, K., Loizidou, M.: Added-value molecules recovery and biofuels production from spent coffee grounds. Renew. Sustain. Energy Rev. 131, (2020). https://doi.org/10.1016/j.rser.2020.110007

26. Caetano, N.S.S., Silvaa, V.F.M., Mata, T.M., Silva, V.: Valorization of coffee grounds for biodiesel production. Chem. Eng. Trans. 26, 267-272 (2012). https://doi.org/10.3303/CET1226045

27. Sluiter, A., Hames, B., Ruiz, R., Scarlata, C., Sluiter, J., Templeton, D., Crocker, D.: Determination of structural carbohydrates and lignin in biomass: Laboratory Analytical Procedure (LAP) (NREL/TP-510-42618). Natl. Renew. Energy Lab. 17 (2012). https://doi.org/NREL/TP-510-42618

28. Miller, G.L.: Use of Dinitrosalicylic Acid Reagent for Determination of Reducing Sugar, (1959)

29. Rojas-Chamorro, J.A., Romero-García, J.M., Cara, C., Romero, I., Castro, E.: Improved ethanol production from the slurry of pretreated brewers' spent grain through different co-fermentation strategies. Bioresour. Technol. 122367 (2019). https://doi.org/10.1016/j.biortech.2019.122367

30. Kemppainen, K., Rommi, K., Holopainen, U., Kruus, K.: Steam explosion of Brewer's spent grain improves enzymatic digestibility of carbohydrates and affects solubility and stability of proteins, (2016)

31. Mussatto, S.I., Dragone, G., Roberto, I.C.: Brewers' spent grain: generation, characteristics and potential applications, (2006)

32. Mussatto, S.I., Carneiro, L.M., Silva, J.P.A., Roberto, I.C., Teixeira, J.A.: A study on chemical constituents and sugars extraction from spent coffee grounds. Carbohydr. Polym. 83, 368-374 (2011).

https://doi.org/10.1016/j.carbpol.2010.07.063

33. Cruz-Lopes, L., Domingos, I., Ferreira, J., Esteves, B.: A New Way of Using Spent Coffee Ground. J. Int. Sci. Publ. 5, 85-93 (2017)

34. Kwon, E.E., Haakrho, Y., Jeon, Y.J., Yi, H., Jeon, Y.J.: Sequential co-production of biodiesel and bioethanol with spent coffee grounds. Bioresour. Technol. 136, 475-480 (2013). https://doi.org/10.1016/j.biortech.2013.03.052

35. Ballesteros, L.F., Teixeira, J.A., Mussatto, S.I.: Chemical, Functional, and Structural Properties of Spent Coffee Grounds and Coffee Silverskin. Food Bioprocess Technol. 7, 3493-3503 (2014). https://doi.org/10.1007/s11947-014-1349-z 
36. Rojas-Chamorro, J.A., Cara, C., Romero, I., Ruiz, E., Romero-García, J.M., Mussatto, S.I., Castro, E.: Ethanol Production from Brewers' Spent Grain Pretreated by Dilute Phosphoric Acid. Energy and Fuels. 32, 5226-5233 (2018). https://doi.org/10.1021/acs.energyfuels.8b00343

37. Faulds, C.B., Robertson, J.A., Waldron, K.W.: Effect of $\mathrm{pH}$ on the solubilization of Brewers' spent grain by microbial carbohydrases and proteases. J. Agric. Food Chem. 56, 7038-7043 (2008). https://doi.org/10.1021/jf800433c

38. Mussatto, S.I.: Brewer's spent grain: A valuable feedstock for industrial applications. J. Sci. Food Agric. 94, 1264-1275 (2014). https://doi.org/10.1002/jsfa.6486

39. Cruz, R., Cardoso, M.M., Fernandes, L., Oliveira, M., Mendes, E., Baptista, P., Morais, S., Casal, S.: Espresso coffee residues: A valuable source of unextracted compounds. J. Agric. Food Chem. 60, 7777-7784 (2012). https://doi.org/10.1021/jf3018854

40. Girotto, F., Lavagnolo, M.C., Pivato, A.: Spent Coffee Grounds Alkaline Pre-treatment as Biorefinery Option to Enhance their Anaerobic Digestion Yield, (2018)

41. Jönsson, L.J., Martín, C.: Pretreatment of lignocellulose: Formation of inhibitory by-products and strategies for minimizing their effects. Bioresour. Technol. 199, 103-112 (2016). https://doi.org/10.1016/j.biortech.2015.10.009

42. Xie, S., Higgins, M.J., Bustamante, H., Galway, B., Nghiem, L.D.: Current status and perspectives on anaerobic codigestion and associated downstream processes. Environ. Sci. Water Res. Technol. 4, 1759-1770 (2018). https://doi.org/10.1039/c8ew00356d

43. Ximenes, E., Kim, Y., Mosier, N., Dien, B., Ladisch, M.: Deactivation of cellulases by phenols. Enzyme Microb. Technol. 48, 54-60 (2011). https://doi.org/10.1016/j.enzmictec.2010.09.006

44. Graves, T., Narendranath, N. V., Dawson, K., Power, R.: Effect of pH and lactic or acetic acid on ethanol productivity by Saccharomyces cerevisiae in corn mash. J. Ind. Microbiol. Biotechnol. 33, 469-474 (2006).

https://doi.org/10.1007/s10295-006-0091-6

45. Lyra Colombi, B., Silva Zanoni, P.R., Benathar Ballod Tavares, L.: Effect of phenolic compounds on bioconversion of glucose to ethanol by yeast Saccharomyces cerevisiae PE-2. Can. J. Chem. Eng. 96, 1444-1450 (2018). https://doi.org/10.1002/cjce.23114

46. Fernández-Delgado, M., Plaza, P.E., Coca, M., García-Cubero, M.T., González-Benito, G., Lucas, S.: Comparison of mild alkaline and oxidative pretreatment methods for biobutanol production from brewer's spent grains. Ind. Crops Prod. 130, 409-419 (2019). https://doi.org/10.1016/j.indcrop.2018.12.087

47. Dimos, K., Paschos, T., Louloudi, A., Kalogiannis, K.G., Lappas, A.A., Papayannakos, N., Kekos, D., Mamma, D.: Effect of various pretreatment methods on bioethanol production from cotton stalks. Fermentation. 5, 1-12 (2019). https://doi.org/10.3390/fermentation5010005

48. Carvalheiro, F., Duarte, L.C., Medeiros, R., Gírio, F.M.: Optimization of brewery's spent grain dilute-acid hydrolysis for the production of pentose-rich culture media, (2004)

49. Pinheiro, T., Coelho, E., Romaní, A., Domingues, L.: Intensifying ethanol production from brewer's spent grain waste: Use of whole slurry at high solid loadings. N. Biotechnol. 53, 1-8 (2019). https://doi.org/10.1016/j.nbt.2019.06.005

50. Chen, S., Xu, Z., Li, X., Yu, J., Cai, M., Jin, M.: Integrated bioethanol production from mixtures of corn and corn stover. Bioresour. Technol. 258, 18-25 (2018). https://doi.org/10.1016/j.biortech.2018.02.125

51. Imamoglu, E., Sukan, F.V.: The effects of single and combined cellulosic agrowaste substrates on bioethanol production. Fuel. 134, 477-484 (2014). https://doi.org/10.1016/j.fuel.2014.05.087

52. Ge, Y., Li, L., Yun, L.: Modeling and economic optimization of cellulosic biofuel supply chain considering multiple conversion pathways. Appl. Energy. 281, 116059 (2021). https://doi.org/10.1016/j.apenergy.2020.116059

53. Mafe, O.A.T., Davies, S.M., Hancock, J., Du, C.: Development of an estimation model for the evaluation of the energy requirement of dilute acid pretreatments of biomass. Biomass and Bioenergy. 72, 28-38 (2015). https://doi.org/10.1016/j.biombioe.2014.11.024 


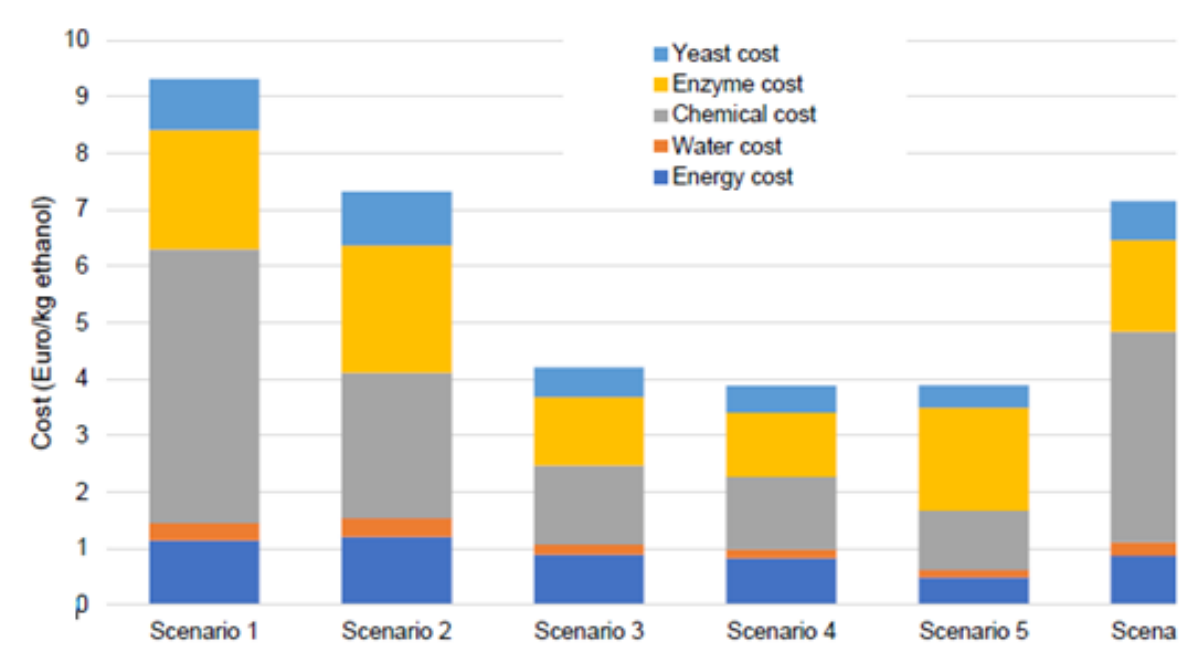

\section{Figure 1}

Scenario 1: SCG ( $\mathrm{NaOH}$ pretreatment $(0.5 \mathrm{~N}, 5 \mathrm{~h})$, enzymatic hydrolysis ( $400 \mu \mathrm{L} / \mathrm{g}$ cellulose, $5 \mathrm{~h}) \mathrm{BSG}(\mathrm{H} 2 \mathrm{SO} 4$ pretreatment $(0.5 \mathrm{~N}, 5 \mathrm{~h})$, enzymatic hydrolysis ( $400 \mu \mathrm{L} / \mathrm{g}$ cellulose, $5 \mathrm{~h})$ Scenario 2 : SCG/BSG mixture, chemical pretreatment $(0.5 \mathrm{~N}, 5 \mathrm{~h})$, enzymatic hydrolysis ( $400 \mu \mathrm{L} / \mathrm{g}$ cellulose, $5 \mathrm{~h}$ ) Scenario 3: SCG/BSG mixture, chemical pretreatment $(0.5 \mathrm{~N}, 16 \mathrm{~h})$, enzymatic hydrolysis $(400 \mu \mathrm{L} / \mathrm{g}$ cellulose, $5 \mathrm{~h})$ Scenario 4: SCG/BSG mixture, chemical pretreatment $(0.5 \mathrm{~N}, 5 \mathrm{~h})$, enzymatic hydrolysis $(400 \mu \mathrm{L} / \mathrm{g}$ cellulose, $16 \mathrm{~h})$ Scenario 5: SCG/BSG mixture, chemical pretreatment $(0.5 \mathrm{~N}, 5 \mathrm{~h})$, enzymatic hydrolysis $(800 \mu \mathrm{L} / \mathrm{g}$ cellulose, $5 \mathrm{~h})$ Scenario 6: SCG/BSG mixture, chemical pretreatment $(1 \mathrm{~N}, 5 \mathrm{~h})$, enzymatic hydrolysis $(400 \mu \mathrm{L} / \mathrm{g}$ cellulose, $5 \mathrm{~h})$

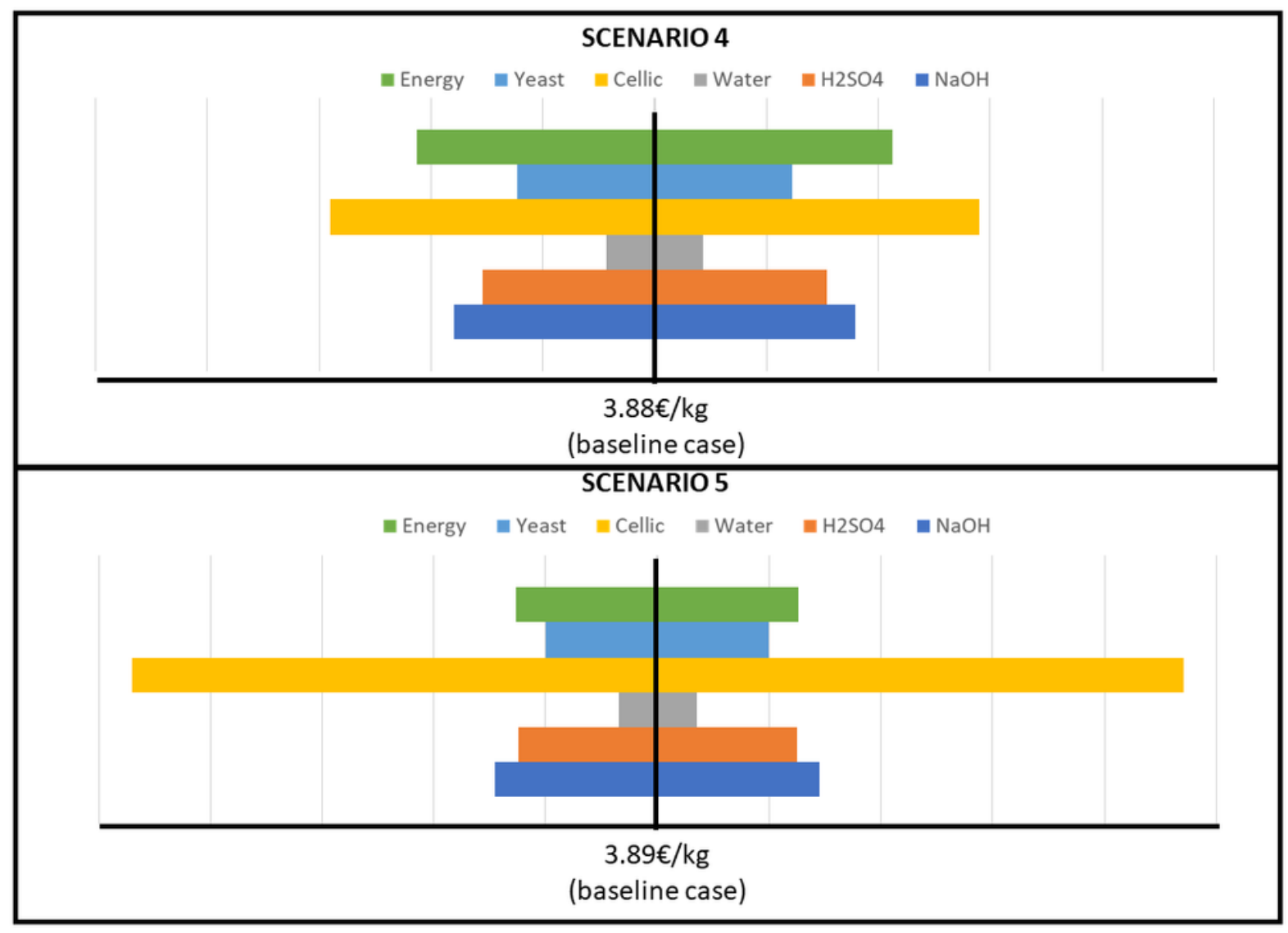




\section{Figure 2}

Sensitivity analysis results

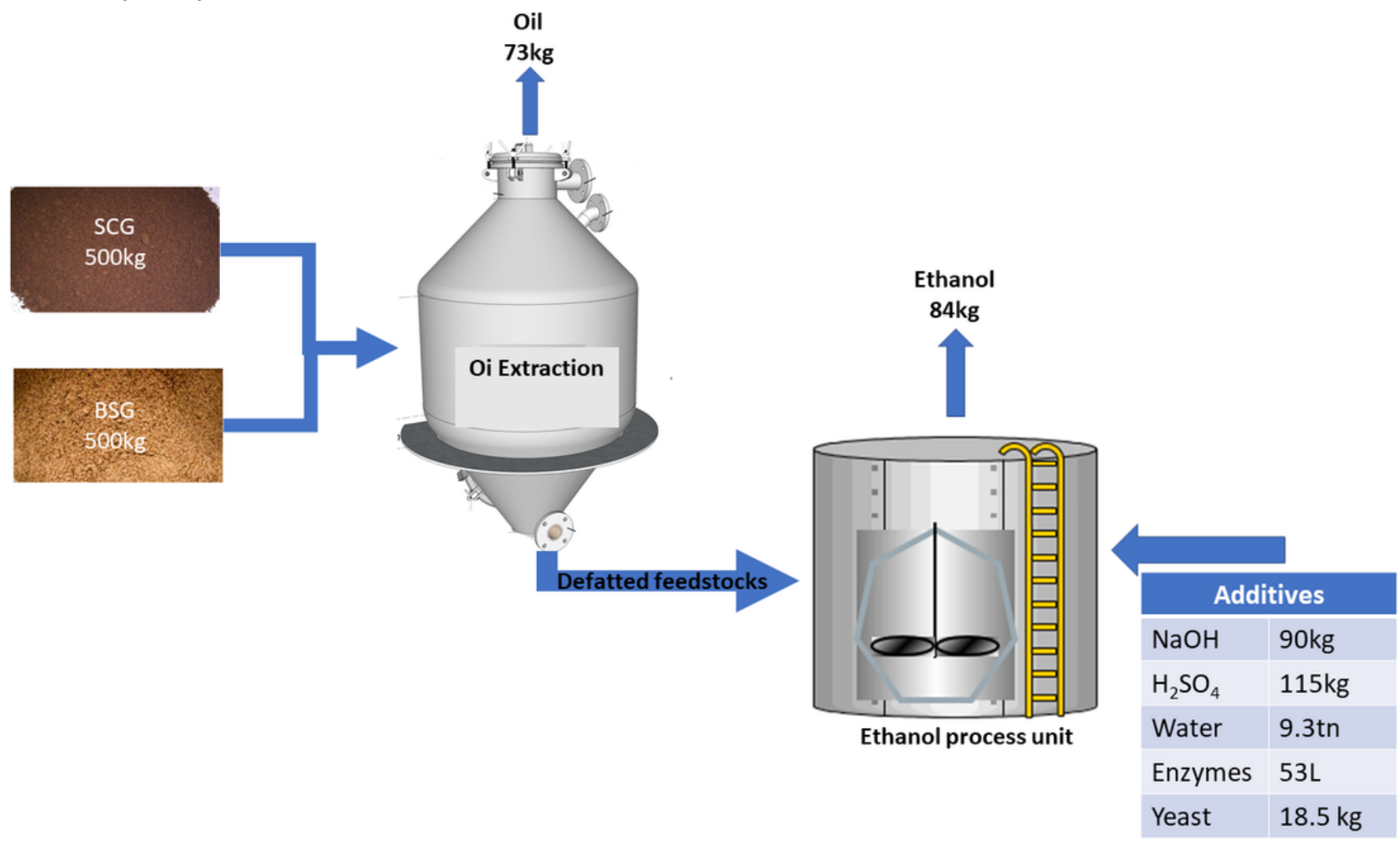

\section{Figure 3}

Integrated multi-feedstock biorefinery

\section{Supplementary Files}

This is a list of supplementary files associated with this preprint. Click to download.

- Newgraphicalabstract.pptx 